\title{
A FUZZY LOGIC REASONING BASED REAL TIME ENERGY PRICE REGULATION APPROACH FOR SMART GRIDS
}

\author{
Recep Çakmak, Ahmet Çakanel
}

1Department of Electrical and Electronics Engineering, Gümüşhane University/ Gümüşhane, Turkey, rcakmak@gumushane.edu.tr (https://orcid.org/0000-0002-6467-6240)

\begin{tabular}{lr}
\multicolumn{2}{c}{${ }^{1}$ Department of Electrical and Electronics Engineering, Gümüşhane University/ Gümüşhane, Turkey, acakanel@gmail.com } \\
(https://orcid.org/0000-0003-2988-325X)
\end{tabular}

\begin{abstract}
Intelligent technologies have become pioneer force to provide flexible, dynamic and efficient energy generation and management. Thus, smart algorithms such as fuzzy logic, artificial neural network, machine learning, soft computing techniques are sole remedy against growing diverse and numerous distributed generations that make more complicated power systems. Real time closed loop controlling requires energy price as a featured variable to procure supply demand equilibrium point for a stable and reliable power system operation, where several dynamic models and estimation software are introduced in the literature. In this study, a fuzzy logic reasoning-based price regulator (FLR-PR) is designed and simulated on MATLAB/Simulink environment using 2018 hourly data of a summer day taken from annual energy report of Turkey. The proposed model has been compared to Proportional Integral Derivative (PID) price controller based on performance indexes in the constituted simulation cases. FLR-PR tracks instant reference demand signal changes with minimum steady state error and fast transient response with respect to PID controller.
\end{abstract}

Keywords: Energy pricing, Fuzzy logic, Performance indexes, PID controller, Smart grids.

\section{AKILLI ŞEBEKELER ICÇİN BULANIK MANTIĞA DAYALI GERÇEK ZAMANLI ENERJI FIYYTI DÜZENLEME YAKLAŞIMI}

\section{Özet}

Akıllı teknolojiler esnek, dinamik, verimli enerji üretimi ve yönetimini sağlamada öncü bir role sahiptir. Bu nedenle bulanık mantık, yapay sinir ağı, makine öğrenmesi, yumuşak hesaplama teknikleri gibi akıllı algoritmalar çeşitli ve çok sayıdaki dağıtık üretimlerin daha karmaşık hale getirdiği güç sistemleri için tek çaredir. Gerçek zamanlı kapalı çevrim kontrolü, literatürde yer alan çeşitli dinamik modellerin ve tahmin yazılımının istikrarlı ve güvenilir güç sistemi işletiminin sağlaması için arz ve talep denge noktasının temininde öne çıkan bir değişken olarak enerji fiyatını kullanmaktadır. Bu çalışmada bulanık mantığa dayalı bir fiyat düzenleyicisi (BMD-FD) tasarlanıp Türkiye'nin 2018 yılına ait yıllık enerji raporundan alınan bir yaz gününün saatlik verisi ile MATLAB/Simulink ortamında tasarlanan sistemin benzetimi yapılmıștır. Önerilen model olușturulan benzetim durumlarında Oransal Integral Türev (PID) fiyat denetleyicisi ile performans kriterlerine göre karşılaştırılmıştır. BMD-FD anlık referans talep sinyali değişikliklerini PID denetleyiciye göre daha hızlı geçici yanıt tepkisi ve minimum sürekli durum hatasıla takip etmektedir.

Anahtar Kelimeler: Enerji fiyatlandırması, Bulanık mantık, Performans kriterleri, PID denetleyici, Akıllı şebekeler.

Cite

Cakmak, R., Çakanel, A. (2019). “A fuzzy logic reasoning based real time energy price regulation approach for smart grids”, Mugla Journal of Science and Technology, 5(1), 143-150.

\section{Introduction}

Various renewable energy sources are diversely utilized on inevitably untidy locations resulting in uncertain and varying power generation in the main grid. Even though distributed power generation systems (DPGS) suffer from low efficiency and high dependency on elements of nature like wind and sun-light, they gained full acceptance as a matter of course against drastically increasing energy demand as a regulatory or/and complementary manner of main power supply system. It is likely that DPGS possess a large portion of total energy generation in the future because of incontrovertible needs of clean technologies [1-3]. Nonetheless, utility interconnection standards require diligent control methods to avoid power instability or undesirable failures along with overmuch cost energy pricing, where 
smart grids can deliver such required flexibility in power management to response any altering demand-supply balance. Nayanatara et al. have proposed Probability Based Incremental learning (PBIL) and Micro Genetic Algorithm (MGA) which provides increase in stability of electricity grid along with reduction of losses and cost of generation [4]. A random stochastic search algorithm has been proposed to provide cost efficient energy mixing rates under varying energy price conditions for the multi-source renewable microgrids which include a storage unit [5]. This issue addresses to electric power utilities, smart grid product and service suppliers, owner/operators, stakeholders, regulators and policy makers, assessors, analysts and investigators, customers, standard development organizations, academics and R\&D organizations [6].

The interest of DPGS is increasing each year to meet exponentially rising energy demand in Turkey which brings along aforementioned concerns and pursuit of efficient control methods. Distribution of each resource types significantly changes each year according to annual reports of Energy Market Regulatory Authority (EMRA). For instance, the amount of unlicensed generation increased by $166,42 \%$ in 2017 compared to the previous year [7]. Detailed information for licensed and unlicensed generation according to resource types is given in Table I and Table II.

Many different dynamic supply-demand models are introduced to prevent untimely shortages and over-billing to costumers, where they all embrace a relative response delay time and oversupplying during day. Energy price as a parameter preeminently affects to both demand and supply sides and along with emerging smart grids, it should be regulated and controlled by a smart control and management systems [1].

Table 1. Licensed Energy Generation in Turkey [7].

\begin{tabular}{|l|r|r|r|c|c|}
\hline $\begin{array}{c}\text { Resource } \\
\text { Type }\end{array}$ & $\begin{array}{c}\text { 2016 } \\
\text { (MWh) } \\
\text { x10 }\end{array}$ & $\begin{array}{c}\text { Share } \\
\mathbf{( \% )}\end{array}$ & $\begin{array}{c}\text { 2017 } \\
\text { (MWh) } \\
\mathbf{x 1 0}^{6}\end{array}$ & $\begin{array}{c}\text { Share } \\
\mathbf{( \% )}\end{array}$ & $\begin{array}{c}\text { Change } \\
\text { (\%) } \\
\mathbf{2 0 1 6 - 2 0 1 7}\end{array}$ \\
\hline Natural gas & 88.2 & 32,38 & 108.7 & 37,18 & 23,26 \\
\hline Imported coal & 47.7 & 17,52 & 51.2 & 17,49 & 7,19 \\
\hline Hydro dam & 48.9 & 17,94 & 41.3 & 14,11 & $-15,60$ \\
\hline Lignite & 38.5 & 14,14 & 40.5 & 13,86 & 5,19 \\
\hline Wind & 15.5 & 5,69 & 17.9 & 6,10 & 15,22 \\
\hline Run of river & 18.4 & 6,75 & 17.1 & 5,85 & $-6,88$ \\
\hline Geothermal & 4.8 & 1,77 & 6 & 2,04 & 23,89 \\
\hline Hard coal & 3.3 & 1,21 & 3.5 & 1,18 & 4,90 \\
\hline Asphaltite coal & 2.9 & 1,05 & 2.4 & 0,82 & $-16,67$ \\
\hline Biomass & 1.6 & 0,58 & 2 & 0,69 & 26,05 \\
\hline Diesel & 1.5 & 0,57 & 1 & 0,34 & $-35,09$ \\
\hline Fuel oil & 1.05 & 0,39 & 0.9 & 0,33 & $-9,13$ \\
\hline Solar & 2.6 & 0,00 & 0.02 & 0,01 & 831,35 \\
\hline Lng & 43 & 0,02 & 0.002 & 0,00 & $-94,89$ \\
\hline Total & $\mathbf{2 7 3}$ & $\mathbf{1 0 0 , 0 0}$ & $\mathbf{2 9 3}$ & $\mathbf{1 0 0 , 0 0}$ & $\mathbf{7 , 3 4}$ \\
\hline
\end{tabular}

There are many studies $[2,3,8-10,13]$ in the literature that have been proposed for dynamic and automated energy price generation systems, while the studies $[2-3,8]$ related to the automated price generation systems emphasize on demand side. Samadi et al. [9] have proposed an optimal pricing scheme in smart grids to provide benefits for both costumers and energy suppliers. Pourbabak et al. [10] have introduced an algorithm for solving the economic dispatch problem of DPGS. Tao and Gao [11] have claimed a real-time pricing for smart grids by considering multiple suppliers and multiple consumers. They have proposed a mechanism to model the utility companies' profit maximization problem. Fioravanti et al. [12] have discussed the utilization of classical control theory applications on problems in smart grids and smart cities. They have claimed that most of classical controllers are not applicable for utilization in these subjects.

Conventional control methods like PID are utilized for price regulations for both demand and supply sides of smart grids. A real-time closed-loop energy price controller has been introduced in [13] for hourly demand fluctuations, where authors have presented a PID (proportional - integral - derivative) controller with a preset case study model, yet its parameters must be reset for any system changes. Furthermore, PID response time is considerably late to prevent shortages which are handled with taking account of a virtual demand rate for the shortage resistance. Either adding on a virtual demand or tuning PID parameters results in over-billing on the customer side even though it is safe solution for system dynamics. System control performance has been improved through the fractional-order PI controller by considering the balance error estimation and price broadcasting delays [14]. While in [13-14] PI and PID controller have been utilized to manage the supply side price, Kaygusuz [15] has proposed a PI controller which regulates the demand side price to ensure an equilibrium between demand and generation in an electricity grid.

Table 2. Unlicensed Energy Generation in Turkey [7].

\begin{tabular}{|l|r|c|r|c|}
\hline \multirow{2}{*}{$\begin{array}{c}\text { Resource } \\
\text { Type }\end{array}$} & $\begin{array}{c}\text { 2016 } \\
\text { The amount of } \\
\text { energy given } \\
\text { to the system } \\
\text { as surplus } \\
\text { (MWh) }\end{array}$ & $\begin{array}{c}\text { Share } \\
\text { (\%) }\end{array}$ & $\begin{array}{c}\text { The amount of } \\
\text { energy given } \\
\text { to the system } \\
\text { as surplus } \\
\text { (MWh) }\end{array}$ & $\begin{array}{c}\text { Share } \\
\text { (\%) }\end{array}$ \\
\hline Solar (PV) & $1.031 .358,00$ & 90,64 & $2.836 .553,09$ & 93,57 \\
\hline Biomass & $92.129,90$ & 8,10 & $138.657,08$ & 4,57 \\
\hline Wind & $8.268,44$ & 0,73 & $36.801,92$ & 1,21 \\
\hline Hydraulic & $6.115,42$ & 0,54 & $19.434,29$ & 0,64 \\
\hline Natural Gas & 0,00 & 0,00 & 111,67 & 0,00 \\
\hline Total & $\mathbf{1 . 1 3 7 . 8 7 1 , 7 5}$ & $\mathbf{1 0 0 , 0 0}$ & $\mathbf{3 . 0 3 1 . 5 5 8 , 0 5}$ & $\mathbf{1 0 0 , 0 0}$ \\
\hline
\end{tabular}

Along with increasing decentralized generation, the complexity in smart grids and their control methods require even more sophisticated monitoring models to meet the desired efficiency and reliability with an upmost positive effect on economy. There are such models like Smart Grid Interoperability Maturity Model, Smart Grid Conceptual Model and Smart Grid Investment Model to follow transmission, distribution and demand 
side resources [16]. Pricing strategies contemplate the unit price and weather conditions on supply side, comfort requirements and electricity availability from decentralized generation on demand side whether to use or store or sell electricity. This pricing mechanism instructs adequate information, a facilitated control and smart decision tools which lacks thorough understating of demand response programs, high cost of technologies and a tiresome turbulent progress of getting dynamic pricing information [17]. As it stands, demand sensitive strategies have become inevitable standard power pricing instruments which all are aimed to find equilibrium point (P) shown in Figure 1.

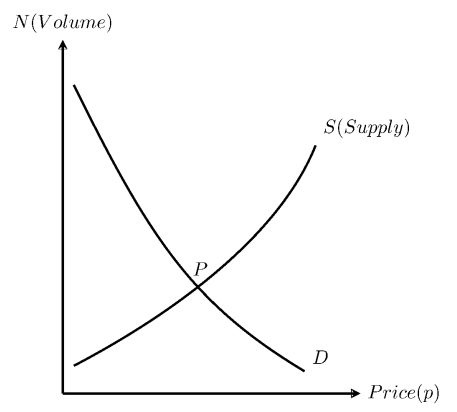

Figure 1. Supply-demand curve.

In this study, a new fuzzy logic based real time energy price controller is proposed and compared with a PID based energy price controller. The uncertainty of energy demand and supply lets authors brought a softcomputing solution with only restoring the fuzzy ruletable if necessary, instead of a deterministic approach which requires resetting system parameters at every turn fails. The remainder of this study is organized as follows. In Section 2, the structure and design of proposed fuzzy logic in dynamic price regulation has been discussed. In Section 3, simulation results have been presented along with discussion on controller performance obtained from case studies via acquired real demand and supply data from Turkish Electricity Transmission Corporation (TEIAS) Load Dispatch Information System [18]. This paper has been concluded in Section 4.

\section{Fuzzy Logic Approach in Dynamic Price Regulation}

In [13] a closed loop energy price control method with a PID is introduced, yet it requires new approaches to meet real-time performance for several reasons. A PID controller has late response time by its nature and requires system parameters which need a tune-up for any changes in supply line. The PID controller obligates mathematical model of the power system which actually has a complex, nonlinear nature that is not entirely applicable in this case [13]. Additionally, a virtual demand is introduced as a margin in order to avoid constant energy shortages which inflates the energy price for customers. In this study, authors aimed to overcome such handicaps with a fuzzy logic reasoningbased price regulation approach used to regulate realtime energy price to ensure an equilibrium point between supply and demand. FLR-PR applied on the power generation system along with demand side in general is given below.

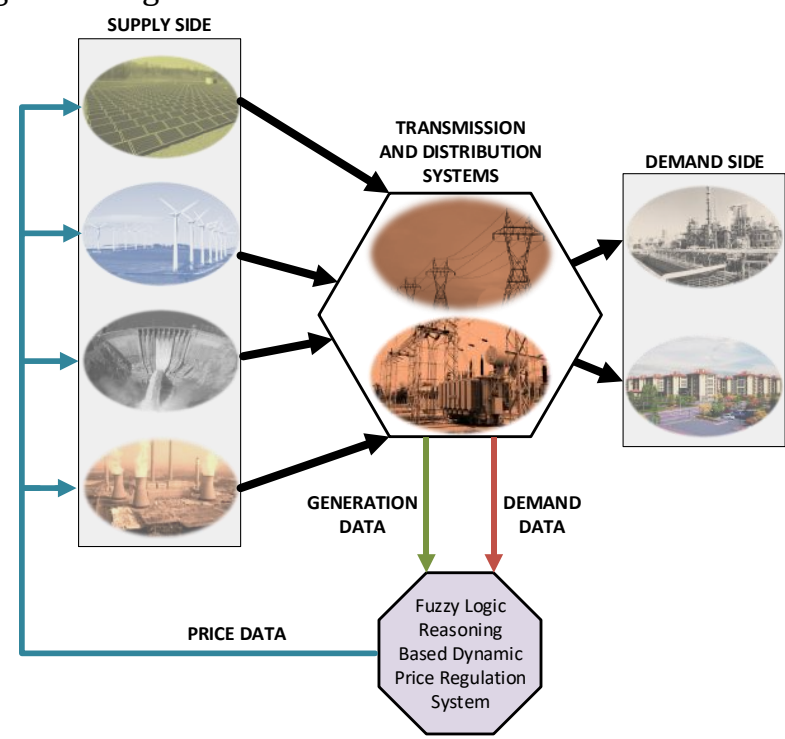

Figure 2. Power system model with proposed fuzzy logic price regulation system.

The main advantage of the fuzzy logic controller (FLC) is designing the controller by linguistic variables by means of human operator's decisions and rules. The operator does not need a mathematical model of the system, cause, the operator adjusts and determines the rules in order to get a desired output by the FLC. So, FLCs are quite appropriate controllers for nonlinear, complex and uncertain systems like multi source power grids. The performance of the FLC can be increased through an effective rule table and a few optimal membership function parameters. Therefore, an uncontrolled system outputs must be analyzed carefully [19-20] and the rules must be arranged effectively in order to get the desired output.

The proposed FLC takes supply and demand difference $(e)$, and their change in time (de) as its inputs. FLC output's change in time $(\mathrm{du})$ 's space is represented in the space of $e$ and $d e$ which each are portioned in 5 linguistic variable segments as Negative Big (NB), Negative Small (NS), Zero (ZZ), Positive Small (PS) and Positive Big (PB). Membership functions and input/output universes are illustrated in Figures 3, Figure 4 and Figure 5.

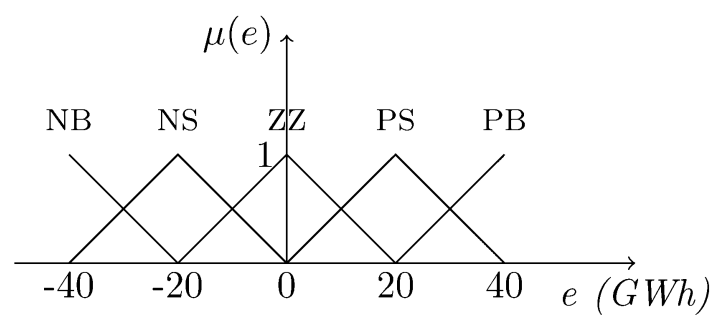

Figure 3. Membership function of error $(e)$. 


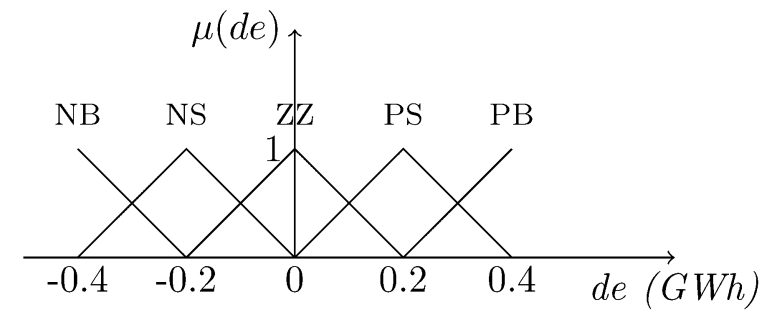

Figure 4. Membership function of derivative of error (de).

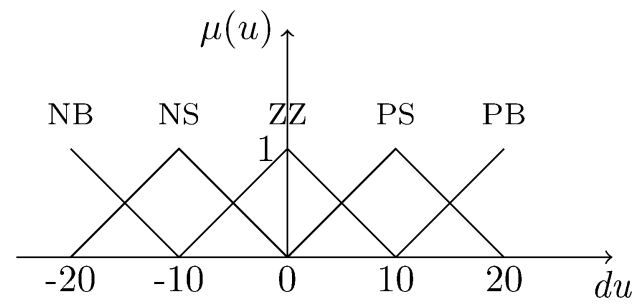

Figure 5. Membership function of FLC output ( $d u$ ).

Step response of a system is needed to create the fuzzy rules of FLC. Step demand system response is assumed as Figure 6. In order to determine fuzzy rules, $e$ and its change in time analyzed in eight different regions through $A$ to $H$ respectively.

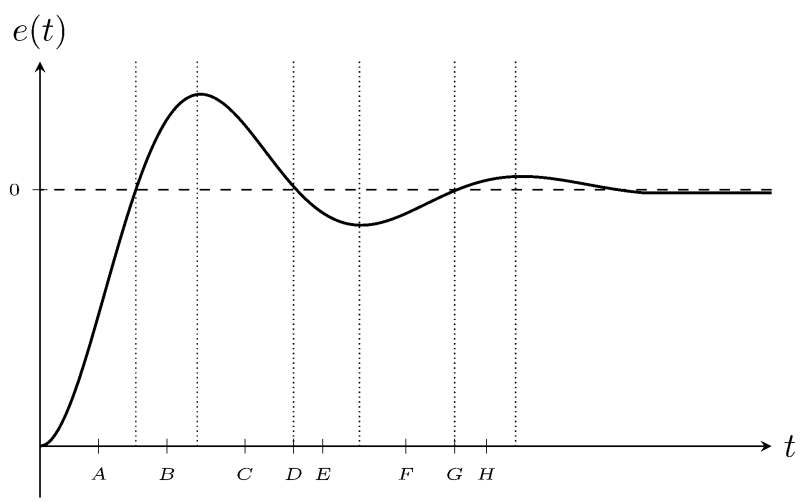

Figure 6. Step response of a power system.

Difference signs in supply and demand and their derivatives are tabulated for each region below and the required control signal signs are assigned accordingly in Table 3 . For example, in region $\mathrm{A}, e$ has a negative sign and its derivative has a positive; intuitively this gives a negative control signal.

Table 3. Signs of $e$, de and $u$ through A to $\mathrm{H}$

\begin{tabular}{|c||c|c|c|c|c|c|c|c|}
\hline Regions $\rightarrow$ & A & B & C & D & E & F & G & H \\
\hline \hline e & - & + & + & 0 & - & - & 0 & + \\
\hline de & + & + & - & - & - & + & + & + \\
\hline $\mathbf{u}$ & - & + & + & - & - & - & + & + \\
\hline
\end{tabular}

Subsequently, the fuzzy rule base is determined as shown in Table 4. For instance, the case of $e$ is NS and $d e$ is NB; this leads tendency of increase in $e$.

Table 4. Constituted FLC rule table.

\begin{tabular}{|c||c|c|c|c|c|}
\hline e de & NB & NS & ZZ & PS & PB \\
\hline \hline PB & ZZ & PS & PS & PB & PB \\
\hline PS & NS & ZZ & PS & PS & PB \\
\hline ZZ & NS & NS & ZZ & PS & PB \\
\hline NS & NB & NS & NS & ZZ & PS \\
\hline NB & NB & NB & NS & NS & ZZ \\
\hline
\end{tabular}

Thus, the control signal (price) must be NB in order to pull up the error through zero. The rule base could be reformed according to the system operator's objectives, which shows the flexibility of fuzzy logic approach.

August 2018 real supply-demand energy statistical data of Turkey is applied on the introduced FLR-PR approach. The Simulink model of FLC, which is adapted based on [19], is illustrated in Figure 7. The simulation outputs of the designed FLC and the previously proposed PID controller [13] are compared based on dynamic performance criteria, customer price benefits and the utility efficiency in the next chapter.

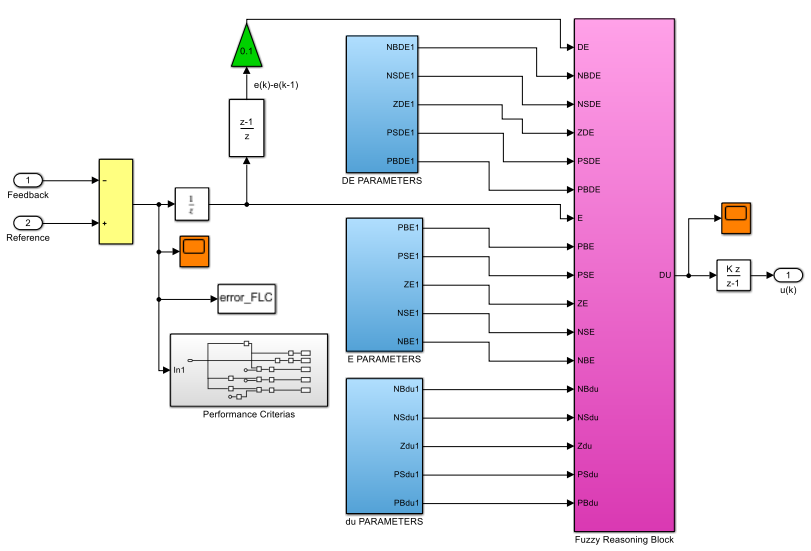

Figure 7. FLC Simulink model.

\section{Case Study}

The utility network of a country has a sort of very large, complex and vibrant feedback system. Such dynamic systems require an effective steady state and transient analysis. To that end, the step response test is used to obtain the stability of a dynamical system which is often utilized in evaluating stability and robustness of control systems such as PID controller and FLC [21]. From this point of view, firstly, the step response analyze is applied on PID and FLC to comprehend the general behavior of the system, which is later for contributed to create the control model of realistic energy data in Turkey. The Simulink model of the case study is illustrated in Figure 8.

\subsection{Step Response Analysis}

The step response analysis example is set up as a demand starts at the beginning of the simulation, increases four times at the end of the first hour and returns to previous value after two hours. In this context, the reference and output signals are represented by demand and supply, respectively.

The price-based generation model is formulated as [13],

$$
G_{i}=G_{i}(p) \frac{1}{\tau_{i} s+1}
$$




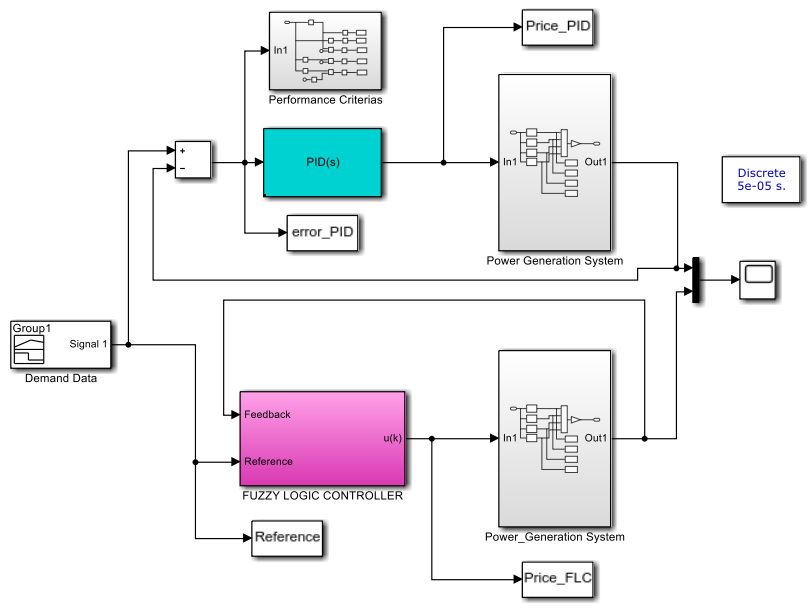

Figure 8. Case study Simulink model.

$G_{i}$ is $i^{\text {th }}$ type of source, $G_{i}(p)$ is the generation volume as a function of price and $\tau_{i}$ is the required time for any source type to reach its maximum capacity. In principle, the total power generation is grounded on this pricebased generation model. The PID compensator model is given as Equation (2).

$$
P+I \frac{1}{S}+D \frac{N}{1+N \frac{1}{S}}
$$

PID controller parameters are selected as $\mathrm{P}=0.178, \mathrm{I}=3.3$, $\mathrm{D}=0.0005$ with filter coefficient $\mathrm{N}=43.01$ to secure the proper supply performance and FLC is designed as described in the previous chapter. The precedent case is simulated with FLC and PID controller and obtained results are shown in Figure 9.

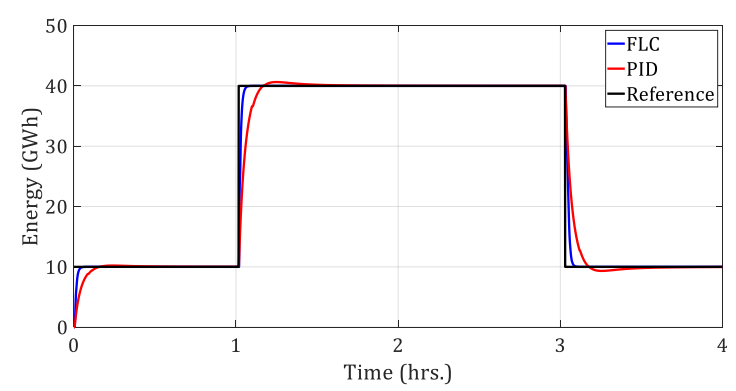

Figure 9. Step response simulation results.

FLC reaches the changing reference signal faster with a minimum overshoot value compared to the PID controller. Supply must constantly follow the trajectory of the demand to ensure a robust, efficient and safe operation of the power systems. Theoretically, the difference between supply and demand tends to zero, however supply is advertently boosted to prevent power shortages due to sudden changes in demand. The positive errors cause shortages in demand and negative errors leads extra-cost for customers as a result of slow tracking performance, illustrated in Figure 10. Rather than avoiding the overbilling case on customer side, it is even more vital to patch shortages by adding on auxiliary power in real life applications. The reference demand value the reach time is 2.82 minutes for FLC while 17.52 for PID, the rise time is 4.98 minutes for FLC while 9.42 for PID and the maximum overshoot value percentage is 0.012 for FLC while 21.6 for PID. FLC surpasses over PID in terms of control parameters. The additional power on FLC based control case will apparently be less than the PID controller, cause FLC responds much faster to rapid changes. Furthermore, FLC overshoot values are considerably less than PID which drains appreciably less power in gigawatts.

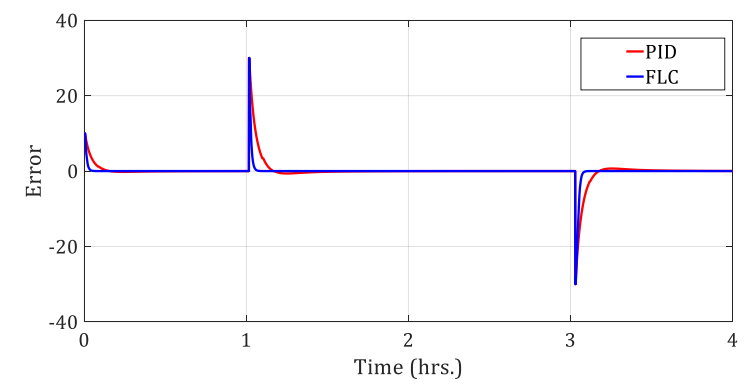

Figure 10. Step response errors in time.

3.2 A simulation of Energy Market Scenario in Turkey

In 2018 Turkey has an 87 MW installed power capacity has taken as a simulation scenario with given portions of energy source types in Table 5. Each power plant production model and its delay time constant rates have taken from [13]. The case study simulations are adapted according to data taken from August 16, 2018 TEIAS, Load Dispatch Information System [18], where various thermic energy sources are combined under the category of 'Thermal', hydropower sources (river, dam) are combined under 'Hydro', licensed and unlicensed solar sources are combined under 'Solar', wind sources are taken as it is and remaining sources ignored with an accordingly adjusted demand value.

Table 5. Case study model of energy generation of Turkey.

\begin{tabular}{|c||c|c|c|c|}
\hline Type & Capacity(MW) & Portion (\%) & $\tau$ (hrs.) & Model \\
\hline \hline Thermal & $46,660.5$ & 53.1 & 0.31 & $\frac{0.01 p^{2}+2.5 p}{(0.05 s+1)}$ \\
\hline Hydro & $28,106.2$ & 32.1 & 0.05 & $\frac{0.01 p^{2}+2.5 p}{(0.05 s+1)}$ \\
\hline Wind & $6,685.1$ & 7.6 & 0.08 & $\frac{0.01 p^{2}+2.5 p}{(0.05 s+1)}$ \\
\hline Solar & $4,792.9$ & 5.4 & 0.05 & $\frac{0.01 p^{2}+2.5 p}{(0.05 s+1)}$ \\
\hline
\end{tabular}

The multi-source energy market pricing based on source type is rationalized according to its capacity and deliverance of consistent relying power supply. The pricing and maximum generation capacity relation logic is illustrated by a flow chart in Figure 11. 


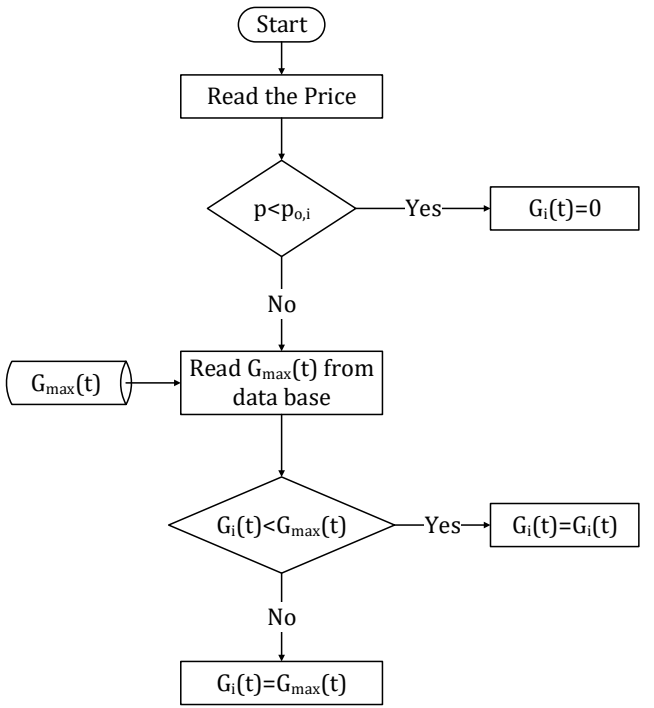

Figure 11. Pricing and maximum generation capacity relation.

In theory, any control algorithm's output signal travels in the vicinity of the reference signal. A remission of the automatic price regulatory systems' output below the instant demand value causes discontinuity of energy transmission and distribution network with energy shortages. Therefore, the previously aforementioned auxiliary power is constituted separately according to a possible maximum difference between demand and supply for both FLC and PID operated applications.

The case without auxiliary power enforced is illustrated in Figure 12. Control algorithms could not track instant, steep demand signal changes properly. For example, PID controller output value is beneath $610 \mathrm{MWh}$ of the required energy while FLC $20 \mathrm{MWh}$ at noon.

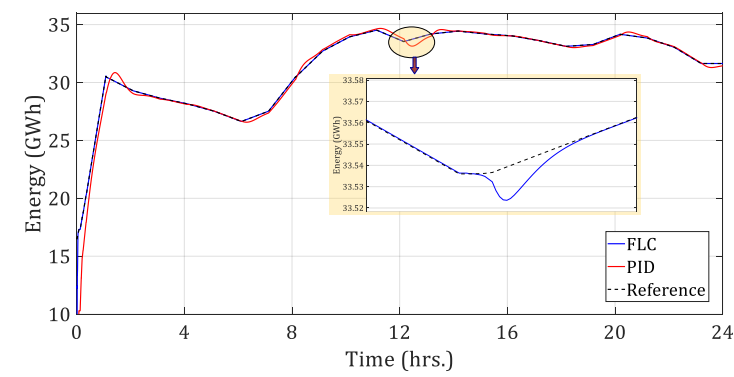

Figure 12. Case study without auxiliary power and appearance of energy shortages.

The apparent solution of adding virtual demand to the real time energy price regulatory model will cause overbilling to the customers, unnecessarily wear out the grid and wasting energy resources. Nonetheless, it is upmost important to adjust reasonable virtual demand to avoid the drawbacks. A properly tuned up virtual demand simulation case for both controllers is illustrated in Figure 13.

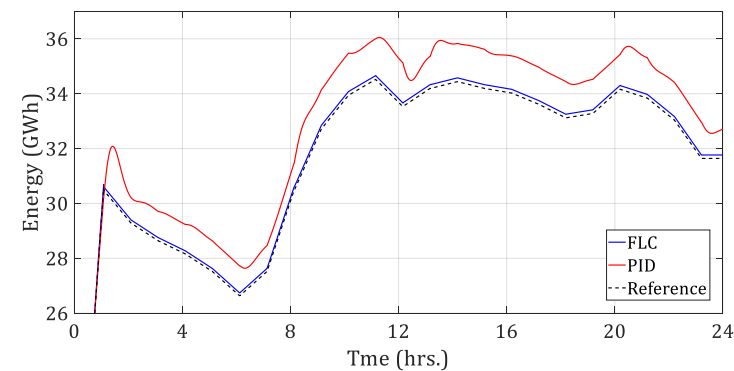

Figure 13. Case study with auxiliary power.

Both real time price regulation methods track hourly instant demand changes with a different accuracy. An optimally tuned PID controller requires approximately 6 percent additional virtual demand in which it is taken 20 percent in [13], where FLC only needs approximately 0.4 percent increase in requisite. In the FLC based regulation case, generation change in time according to the reference demand for four different sources is given in Figure 14.

In the literature, controllers' exercises are compared, analyzed and designed according to performance indexes of IAE (Integral Absolute Error), ISE (Integral Square error), ITAE (Integral Time Absolute Error), ITSE (Integral Time Squared Error) and ISTE (Integral of Squared Time Multiplied by Squared Error).

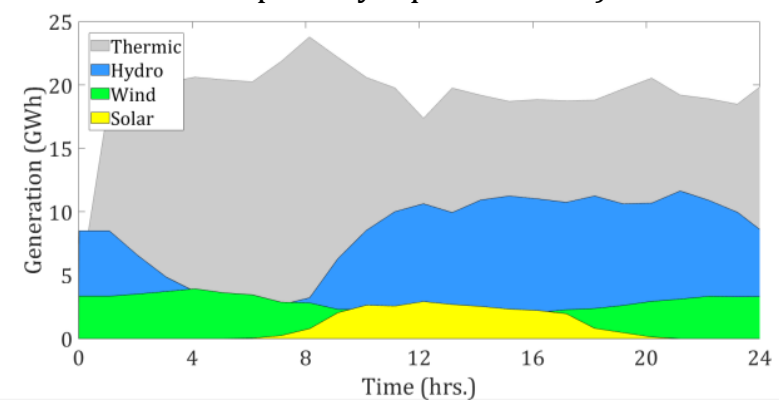

Figure 14. FLC based regulation.

Indexes formulas are given as,

$$
\begin{aligned}
\text { IAE } & =\int_{0}^{T}|e(t)| d t \\
\text { ISE } & =\int_{0}^{T} e^{2}(t) d t \\
\text { ITAE } & =\int_{0}^{T} t|e(t)| d t \\
\text { ITSE } & =\int_{0}^{T} t e^{2}(t) d t \\
\text { ISTE } & =\int_{0}^{T} t^{2} e^{2}(t) d t
\end{aligned}
$$

The comparison of PID and proposed FLC in real time price regulators based on the performance indexes' results are given in Table 6.

Table 6. Performance criteria results.

\begin{tabular}{|c|l|l|l|l|l|}
\hline Control Methods & IAE & ISE & ITAE & ITSE & ISTE \\
\hline PID & 5.86 & 14.15 & 37.71 & 10.63 & 129.1 \\
\hline FLC & 0.14 & 1.21 & 0.05 & 0.005 & 0.001 \\
\hline
\end{tabular}

In each indexes the proposed FLC option clearly exceeds PID's results and proves superiority of better transient 
and steady state response bring along grid efficiency, energy and money savings.

\section{Conclusion}

The energy efficiency and its management have become a more crucial issue in each year because of limited resources and environmental concerns. An inevitable increase in variety and number of distributed energy sources starves more intelligent approaches like fuzzy logic, artificial neural networks on the electrical power systems. It has become imperative to excel Smart Grid concepts and the dynamic pricing in our world. Thus, it seems real time closed loop energy price regulation systems will replace current energy pricing methods entirely as it is expected in Turkey. In the literature, several dynamic supply-demand models and estimation software are presented.

In this study, fuzzy logic reasoning-based price regulator is proposed and compared with a PID controller in performance indexes with using 2018 Turkey's hourly energy data of a summer day. The step response of the proposed design returns with a faster response of $83.9 \%$ for reach time, $47.1 \%$ for rise time and along with $99,9 \%$ lower maximum overshoot value. Supply side provides an additional virtual demand in order to avoid undesired power shortages. In the case studies, the PID controller requires at least $6 \%$ more power generation to cope with the shortages while FLR-PR settles with only a $0.4 \%$ which lowers the unit energy price considerably. Additionally, controller design options are compared regarding to performance criteria indexes which reveal the superiority of the proposed FLR-PR over the PID controller in each index.

\section{References}

[1] Kakran, S. and Chanana, S., "Smart operations of smart grids integrated with distributed generation: A review", Renewable and Sustainable Energy Reviews, 81, pp. 524-535, 2018.

[2] Kong, P. Y., "Effects of communication network performance on dynamic pricing in smart power grid", IEEE Systems Journal, Vol. 8(2), pp. 533-541, 2014.

[3] Qian, L. P., Zhang, Y. J. A., Huang, J., and $\mathrm{Wu}, \mathrm{Y}$., "Demand response management via real-time electricity price control in smart grids", IEEE Journal on Selected areas in Communications, 31 (7), pp. 1268-1280, 2013.

[4] Nayanatara, C., Baskaran, J. and Kothari, D. P., "Approach of hybrid PBIL control in distributed generation parameters for IEEE and real time Indian utility system", IET Renewable Power Generation, 11(2), pp. 255-263, 2017.

[5] Keles, C., Alagoz, B. B., Kaygusuz, A., and Alagoz, S., "Cost efficient multi-source energy mixing for renewable energy microgrids by random search optimization". International Artificial Intelligence and Data Processing Symposium (IDAP'16), 2016, pp. 29-33.

[6] Lopes, M., et al., "An automated energy management system in a smart grid context." 2012 IEEE International Symposium on Sustainable Systems and Technology (ISSST), 2012, pp. 1-1.

[7] Republic of Turkey Energy Market Regulatory Authority (EMRA), Annual Report 2017, 2018.

[8] Motamedi, A., Zareipour, H., and Rosehart, W. D., "Electricity Price and Demand Forecasting in Smart Grids", IEEE Trans. Smart Grid, 3(2), pp. 664-674, 2012.

[9] Samadi, P., Mohsenian-Rad, A. H., Schober, R., Wong, V. W., and Jatskevich, J., "Optimal real-time pricing algorithm based on utility maximization for smart grid", First IEEE International Conference on Smart Grid Communications, 2010, pp. 415-420.

[10] Pourbabak, H., Luo, J., Chen, T., and Su, W., "A novel consensus-based distributed algorithm for economic dispatch based on local estimation of power mismatch", IEEE Transactions on Smart Grid, 9(6), pp. 5930-5942, 2018.

[11] Tao, L., and Gao, Y., "Real-Time Pricing for Smart Grid with Multiple Companies and Multiple Users Using Two-Stage Optimization" Journal of Systems Science and Information, 6(5), pp. 435-446, 2018.

[12] Fioravanti, A. R., Mareček, J., Shorten, R. N., Souza, M., and Wirth, F. R., "On classical control and smart cities," 2017 IEEE 56th Annual Conference on Decision and Control (CDC), 2017, pp. 1413-1420.

[13] Alagoz, B. B., Kaygusuz, A., Akcin, M., and Alagoz, S., "A closed-loop energy price controlling method for real-time energy balancing in a smart grid energy market", Energy, 59, pp. 95-104, 2013.

[14] Alagoz, B. B., and Kaygusuz, A., "Dynamic energy pricing by closed-loop fractional-order PI control system and energy balancing in smart grid energy markets", Transactions of the Institute of Measurement and Control, 38(5), pp. 565-578, 2016.

[15] Kaygusuz, A., "Closed loop elastic demand control by dynamic energy pricing in smart grids", Energy, 176, pp. 596-603, 2019.

[16] Singhal, A., and Saxena, R. P., "Software models for smart grid" 2012 First International Workshop on Software Engineering Challenges for the Smart Grid (SE-SmartGrids), 2012, pp. 42-45.

[17] Zhu, H., Gao, Y., and Hou, Y., "Real-time pricing for demand response in smart grid based on alternating direction method of multipliers", Mathematical Problems in Engineering, vol. 2018, 10 pages, 2018. https://doi.org/10.1155/2018/8760575.

[18] Turkish Electricity Transmission Corporation (TEIAS), Load Dispatch Information System (YTBS), https://ytbsbilgi.teias.gov.tr/ytbsbilgi/frm_istatisti kler.jsf, visit date: 28 December, 2018.

[19] Altas, I. H., and Sharaf, A. M., "A generalized direct approach for designing fuzzy logic controllers in Matlab/Simulink GUI environment", International 
journal of information technology and intelligent computing, 1(4), pp. 1-27, 2007.

[20] Cakmak, R., Altas, I. H., and Sharaf, A. M., "Modeling of FLC-Incremental based MPPT using DC-DC boost converter for standalone PV system", Innovations in Intelligent Systems and Applications (INISTA) 2012, 2012, pp. 1-5.

[21] O'Dwyer, A., Handbook of PI and PID controller tuning rules, World Scientific, Imperial Collage Press, London, 2009. 